\title{
MATHEMATICAL TEACHING MOMENTS: BETWEEN INSTRUCTION AND CONSTRUCTION
}

\author{
Troels Lange, Tamsin Meaney, Eva Riesbeck, Anna Wernberg \\ Malmö University
}

Internationally there is much discussion about what and how mathematics should be integrated into preschool programs. In Swedish preschools, there is a strong tradition of valorising children's play. Using video data, we identify how one teacher in a Swedish preschool recognises and builds on mathematical teaching moments that arise from children's play. We use this data to discuss how the guided play context facilitates some teacher actions while constraining others. Respectful listening and asking challenging questions seem to stimulate the development of children's mathematical curiosity. However, the teacher is not able to insist that her suggestions for activities are taken up by the children.

\section{MATHEMATICS THROUGH PLAY IN SWEDISH PRESCHOOLS}

Sweden, like other countries such as New Zealand (Haynes, 2000), is faced with a tension of wanting to ensure that children begin school with stronger mathematical understandings, while also wanting to adhere to the philosophy that preschool children should learn through play. This is a tension that some see as irreconcilable (Lee \& Ginsburg, 2009; Carr \& May, 1996), often because it is reduced to an eitheror scenario - either children's own interests are followed or they are directly instructed by an adult (Dijk, van Oers, \& Terwel, 2004). In this paper, we explore how one teacher developed children's mathematical curiosity from their play. Through respectful listening, including watching carefully what children do, the teacher was able to ask questions that simultaneously engaged the children's mathematical curiosity and supported their play.

As is the case in many countries around the world, in Swedish preschools play is considered the foundation for children's learning experiences (Skolverket, 2011). This is reflected in the curriculum:

Play is important for the child's development and learning. Conscious use of play to promote the development and learning of each individual child should always be present in preschool activities. Play and enjoyment in learning in all its various forms stimulate the imagination, insight, communication and the ability to think symbolically, as well as the ability to co-operate and solve problems. (Skolverket, 2011, p. 6)

Connecting play with enjoyment assumes that learning will produce more easily "imagination, insight, communication and the ability to think symbolically, as well as the ability to co-operate and solve problems". However, in a study of Swedish teachers and parents' perceptions of the relationship between play and learning in very young children, learning was taken for granted and considered as something that always occurs in play (Sheridan, Samuelsson, \& Johansson, 2009). It was not something that had to be planned for. At the same time, play was assessed as being of 
low quality, although exactly how this quality was judged was unclear. Still it would seem that the assumption of the connection between play, enjoyment and learning needs more investigation.

One reason for the difficulty in assessing the quality of play may be because it is difficult to define (Samuelsson \& Carlsson, 2008). Alan Bishop (1988) in discussing the addition of play to his list of universal mathematical activities used Norbeck's (1977) reflections on the work of Huizinga to suggest the following list of characteristics:

- voluntary, free

- not a task, not ordinary, not real

- essentially unserious in its goals although often seriously executed

- outside the immediate satisfactions itself, but an integral part of life and a necessity

- repetitive

- closely linked with beauty in many ways but not identical with it

- creates order and is order; has rules, rhythms and harmony

- often related to wit and humour but is not synonymous with them

- has elements of tension, uncertainty, chanciness

- outside the antitheses of wisdom and folly, truth and falsehood, good and evil, vice and virtue, has no more moral function (p. 42)

More succinctly and combining many of the features also identified by Samuelsson and Carlsson (2008), Dockett and Perry's (2010) stated:

The process of play is characterised by a non-literal 'what if' approach to thinking, where multiple end points or outcomes are possible. In other words, play generates situations where there is no one 'right' answer. ... Essential characteristics of play then, include the exercise of choice, non-literal approaches, multiple possible outcomes and acknowledgement of the competence of players. These characteristics apply to the processes of play, regardless of the content. (Dockett \& Perry, 2010, p. 175)

These definitions share several ideas. They include a sense of play being voluntary so that children have a choice of whether to engage or not as well as having choices about how to participate. It could also be said that the uncertainty that is integral to play provides the opportunities for multiple possible outcomes. The "what-if" and "non-literalness" nature of play resonates with play being outside the "antitheses" mentioned by Bishop. While the Dockett and Perry's (2010) definition includes the "acknowledgement of the competence of players", the characteristics discussed by Bishop (1988) do not include any which are related to characteristics of the participants. Play can be considered as an essential component of children's experiences as they explore, try out and interact with aspects of the world around them.

The Swedish curriculum for preschools (Skolverket, 2010) does not define play as such, except by choosing to use the work lek, meaning play without pre-determined rules. (Playing of rule-based games, such as football, bridge and Monopoly, is 
denoted by the word spel.) The choice of the word lek indicates an alignment with Dockett and Perry's (2010) idea that the characteristics of play are about the process, rather than outcomes. In the characteristics discussed by Bishop (1988), rules are mentioned but in the sense that they arise out of the play - "creates order and is order; has rules, rhythms and harmony" - rather than being imposed on the play.

We consider that there are predominantly two kinds of situations which can be described as play in preschools: free play, in which children use the resources around them without adult intervention, and guided play where a teacher sets up a situation but allows children's own interests to form the play. Both of these kinds of play are in alignment with the use of lek in the preschool curriculum. Although researchers used these terms, for example Coltman, Petyaeva, and Anghileri (2002), Edo, Planas and Badillo (2009), Lamberty (2007), the differences between the terms generally remain undefined.

Although it has been documented that mathematical learning has arisen from free play (Coltman, Petyaeva, \& Anghileri, 2002), Lee and Ginsberg (2009) suggested that children are likely to gain only limited mathematical understandings from it. For them, the role of the teacher is of paramount importance. Björklund (2008) showed that adults set the parameters for children's opportunities to engage with mathematical ideas. An adult watching or participating in child-initiated play can develop children's mathematical ideas by stimulating their curiosity and language use (Doverborg, 2006). Anderson (1997) in investigating parent interactions with preschool children wrote:

Adherence to social constructivist principles implies that parents be encouraged to share in determining and carrying out activities with their children rather than to expect children to work alone with the materials. Likewise, it suggests that young children are capable explorers who actively seek meaning from and aptly structure their own engagement with the materials and significant others. (p. 485)

As an alternative to the two types of play, direct instruction also can occur in preschools. In this case, the teacher prescribes what actions the children should engage in. Children may still enjoy this learning but they can make limited, if any, choices about what they do (see Emilson \& Folkesson, 2006). In recent years, particularly in English-speaking countries, several intervention studies have involved teachers presenting preschool children with set activities. For example, Papic, Mulligan and Mitchelmore (2011) implemented an intervention program on repeating and spatial patterning in one preschool over a six month period. Children were grouped according to how they performed on an initial diagnostic interview and then provided with tasks for their level. A combination of individual and group time was provided. Children progressed to the next level if they showed competency in their current level.

Although learning through play can be juxtaposed with learning from direct instruction, such a juxtaposition limits the types of discussions that can result. 
Consequently, we see it as being more valuable to focus on the teaching process and the features most likely to lead to learning. To us, teachers, or other adults, who engage with children around mathematical concepts are teaching. Therefore, teaching can occur both in guided play as well as in direct instruction. The relationship between teaching and learning is complex, making it difficult to determine causality (Krummheuer, 2012). However, by understanding how a teacher interacts with children within a guided play situation, we will be more able to understand which features in the interaction contribute to children's learning mathematics.

In this paper, we first present two models for the organisation of learning before describing, how the Swedish preschool teacher engaged with a small group of children around the mathematical ideas in a set of glass jars. We then use the models to analyse the teacher's role in developing children's mathematical curiosity through building on mathematical teaching moments.

\section{THE TEACHER'S ROLE IN PRESCHOOL CHILDREN'S LEARNING}

The importance of scaffolding, where adults gradually reduce their level of support so children become competent, is often raised in discussions about young children learning mathematics. Frequently, this discussion is framed in relation to children solving problems (Wood, Bruner, \& Ross, 1976). Using her own and others' work on scaffolding, Anghileri (2006) distinguished between different teacher strategies for scaffolding mathematics learning. These strategies can be seen in the three level model represented in Figure 1. Each level is in a hierarchical relationship to the others:

At the most basic level, environmental provisions enable learning to take place without the direct intervention of the teacher. The subsequent two levels identify teacher interactions that are increasingly directed to developing richness in the support of mathematical learning through explaining, reviewing and restructuring and developing conceptual thinking. (Anghileri, 2006, p. 38)

Examples of different strategies are provided at each level. The strategies in the centre are those that Anghileri (2006) considered were seen most frequently in classrooms, while the strategies on the sides were the ones that were more likely to be connected to effective mathematics classrooms. Although situated within the school context, much of the work that Anghileri drew on in developing this model came from research on 4-6 year olds. Given that Swedish children are in preschools for most of this age period, Anghileri's model has the potential to be a valuable resource in analysing the teacher's role in developing children's mathematical curiosity. 

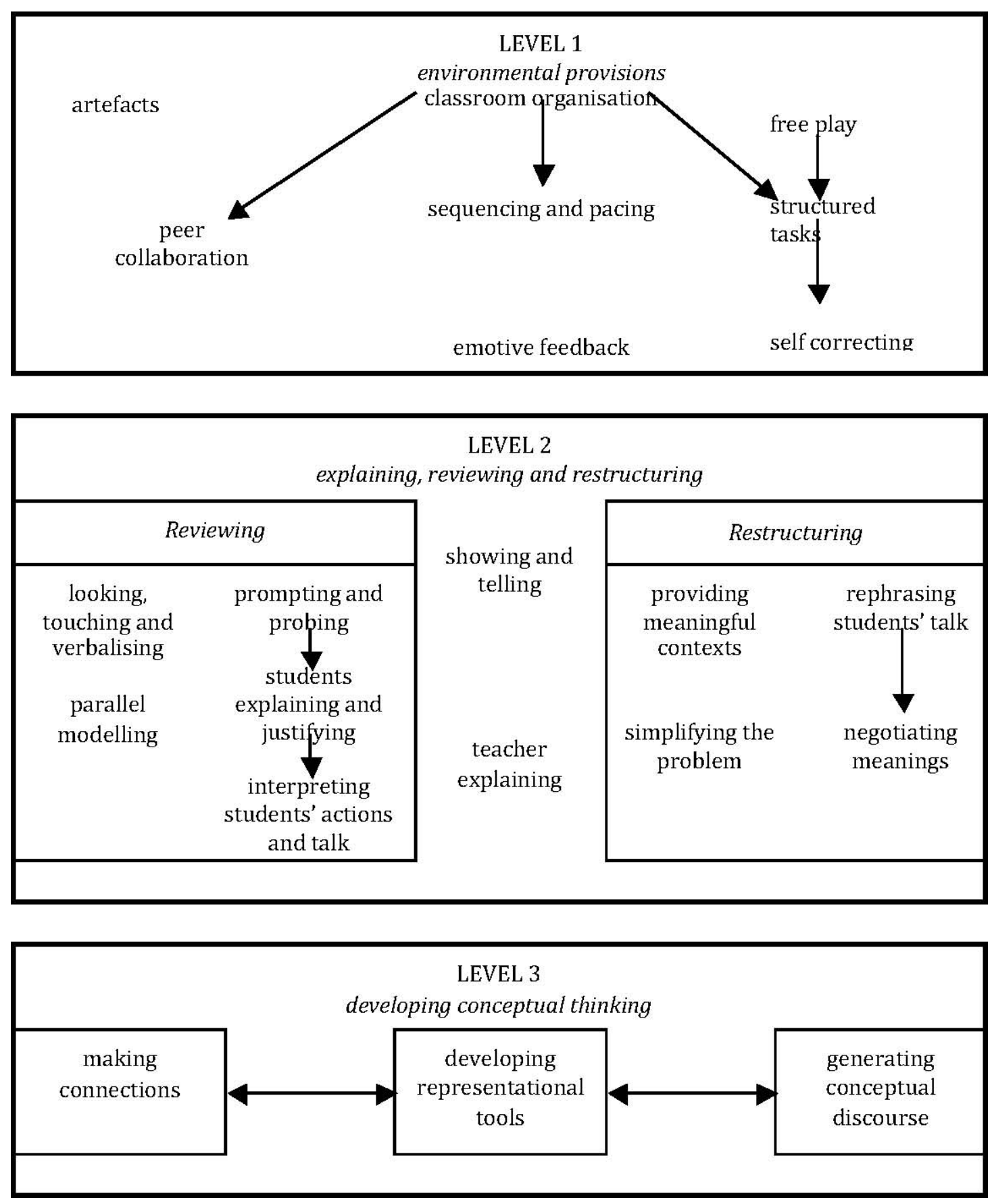

Figure 1: Teacher strategies for scaffolding learning (from Anghileri, 2006, p. 39)

Although Anghileri (2006) acknowledged the importance of the interactions between teachers and students as leading to learning, her model focuses on what the teacher does and the children's actions are less visible. As indicated by Anderson (1997), children are active investigators of their world and thus their contributions to the interactions must be considered, especially when it is from their play that the teacher identifies teaching moments. In a study of toddlers in a Swedish preschool, Emilson and Folkesson (2006) used the ideas of Bernstein to suggest that a teacher, "instead of keeping control by the selection of communication, its sequencing and its pacing, she is responsive, observant and confirming, and she develops the ideas of the children" (p. 237). In so doing she was able to support children to make decisions about their 
learning and consequently be involved in genuine participation. The child's contribution to the interaction was the basis on which learning opportunities were developed. Therefore, although Anghileri (2006) provides valuable insights, there is a need for a broader model with which to analyse interactions between the teacher and the children.

In many ways the description of Emilson and Folkesson's (2006) teacher's interactions with toddlers resembles what Rogoff, Paradise, Arauz, Correa-Chávez and Angelillo (2003) described as intent participation. Rogoff et al. (2003) acknowledge that there are many ways to organise learning, but in their article they distinguished between intent participation and assembly-line instruction. Table 1 shows the main differences between these two types of learning. Intent participation often occurs when "people engage together in a common endeavour" (p. 183) and assembly-line instruction is used when there is a "transmission of information from experts outside the context of purposeful, productive activity" (p. 183), something which they perceived as being common in schools.

Table 1: Multifaceted traditions for organizing learning (from Rogoff, Paradise,

Arauz, Correa-Chávez, \& Angelillo, 2003, p. 185)

\begin{tabular}{|c|c|c|}
\hline & Assembly-line instruction & Intent participation \\
\hline $\begin{array}{l}\text { Participation } \\
\text { structure }\end{array}$ & $\begin{array}{l}\text { Hierarchical participation structure } \\
\text { with fixed roles. }\end{array}$ & $\begin{array}{l}\text { Collaborative, horizontal participation } \\
\text { structure with fluid responsibilities. }\end{array}$ \\
\hline Motivation & $\begin{array}{l}\text { Motivation in extrinsic rewards, } \\
\text { threats. Relation of steps to purpose } \\
\text { often unknown. }\end{array}$ & $\begin{array}{l}\text { Motivation in importance of activity. } \\
\text { Relation of steps to purpose understood. }\end{array}$ \\
\hline Assessment & $\begin{array}{l}\text { Assessment separate from learning, } \\
\text { to test receipt. }\end{array}$ & $\begin{array}{l}\text { Assessment during shared endeavours to } \\
\text { aid learning. }\end{array}$ \\
\hline Communication & $\begin{array}{l}\text { Communication mainly in words; } \\
\text { questions to quiz learners. }\end{array}$ & $\begin{array}{l}\text { Communication through joint action, and } \\
\text { words and gestures about needed } \\
\text { information. }\end{array}$ \\
\hline Learning & $\begin{array}{l}\text { Learning through lessons, } \\
\text { exercises, out of purposeful } \\
\text { endeavours. }\end{array}$ & $\begin{array}{l}\text { Learning through observation during } \\
\text { participation in shared endeavours. }\end{array}$ \\
\hline Roles & $\begin{array}{l}\text { Experts manage, dividing task, not } \\
\text { participating. Learners receive } \\
\text { information. }\end{array}$ & $\begin{array}{l}\text { Experienced people guide while } \\
\text { participating. Learners take initiative. }\end{array}$ \\
\hline
\end{tabular}

Although not specifically on preschool teaching, Rogoff et al.'s (2003) model, like that of Anghileri (2006), drew on extracts from interactions between adults and preschool-aged children to exemplify the different components. Rogoff et al. (2003) considered that it is the integration of the components which contribute to the different traditions for organising learning. Certainly the components of intent participation recognise the role of the child or learner in the interaction. There is an overlap in some aspects of both models; for example, Anghileri's model highlighted 
the need for a teacher to identify meaningful contexts whilst Rogoff et al. suggested that in intent participation, "motivation is generally inherent in the obvious importance and interest of the activity". However, there are also differences. Anghileri concentrated on the teacher whereas Rogoff et al. viewed the roles of the participants as being fluid. We have primarily drawn on Rogoff et al.'s model and used the teacher scaffolding strategies of Anghileri's model to unpack the teacher's role in the interactions with the children.

\section{THE DATA}

The research was undertaken in a private preschool in a large city in southern Sweden. Filming was undertaken with different classes/groups over several days. In this paper we report on one episode of guided play. Although initially the teacher had not nominated it as being a mathematical activity, this focus became evident as the children engaged with the jars. Therefore, it was chosen because it exemplified how the activity was developed from the children's own interests. The whole episode lasted about 11 minutes. Extracts of the transcript are provided in the original Swedish with an English translation.

After first describing the episode, we then analyse how the teacher identified and then elaborated on children's interests by discussing each of the components in Rogoff et al.'s (2003) multifaceted models and connecting them to Anghileri's (2006) teacher strategies for scaffolding for learning.

\section{PLAYING WITH GLASS JARS}

In this episode, three children, Marie, Mia and Lena, all pseudonyms, played with some glass jars. The teacher ( $\mathrm{L}$ in the transcripts) provided the opportunity for this exploration, although the main purpose of the activity was for the children to put coloured paper on the jars and make them into candleholders.

The teacher placed herself on the side of the group and so was at a similar height to the children. This seemed to contribute to them focusing on the jars in the centre of the space. The children continually touched the jars, putting their hands and feet inside and exchanging the jars between themselves.

Most of the time, the teacher sat away from the jars, allowing the children to take the lead. However, when she wanted to ask specific questions or highlight particular aspects of the jars, she would touch or point to them. Although the teacher asked questions, she did not model answers, nor force the children to answer her questions when they showed reluctance.

The teacher began by asking the children if they thought that the jars looked the same. The children explained how they perceived the jars as rectangular, thick or thin. The teacher then asked one of the children, Lena, why she thought her jar was thick. 


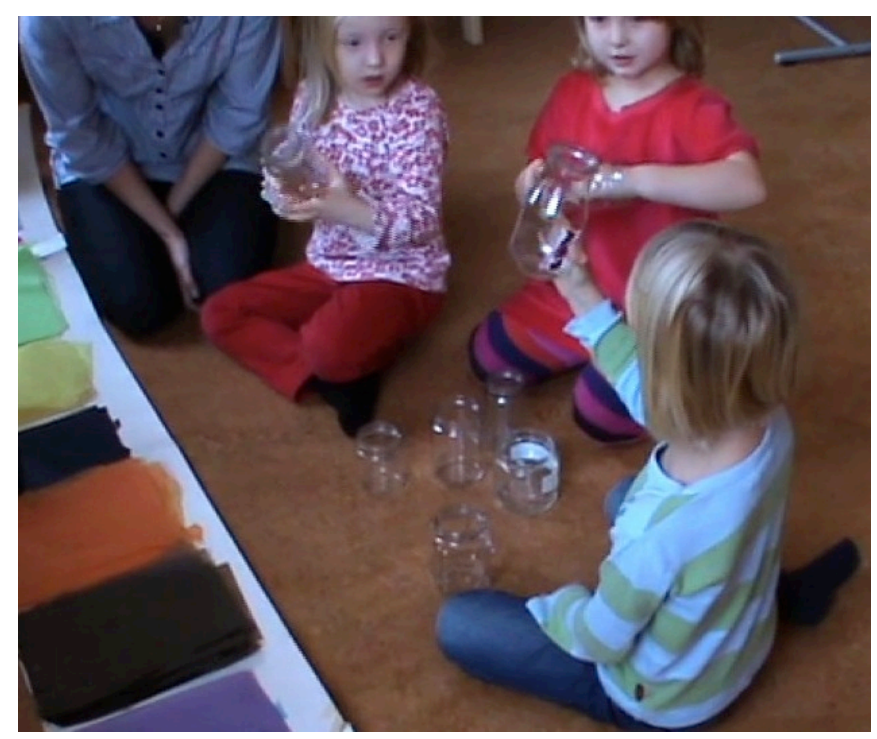

L: $\quad$ Och din är lite tjock. På vad sätt är And yours is a bit thick. In what way is it den tjock Lena, hur är den tjock? thick Lena, how is it thick?

Lena: Den är tjock på denna bredden. It is thick at this width. [the child has a [barnet har en burk som blir jar that gets thicker at the bottom which tjockare nertill som hon visar på] she demonstrates]

The teacher then continued by asking if the children had noticed other shapes.

L: Har den någon annan form någon Does it have any other shape elsewhere? annanstans?

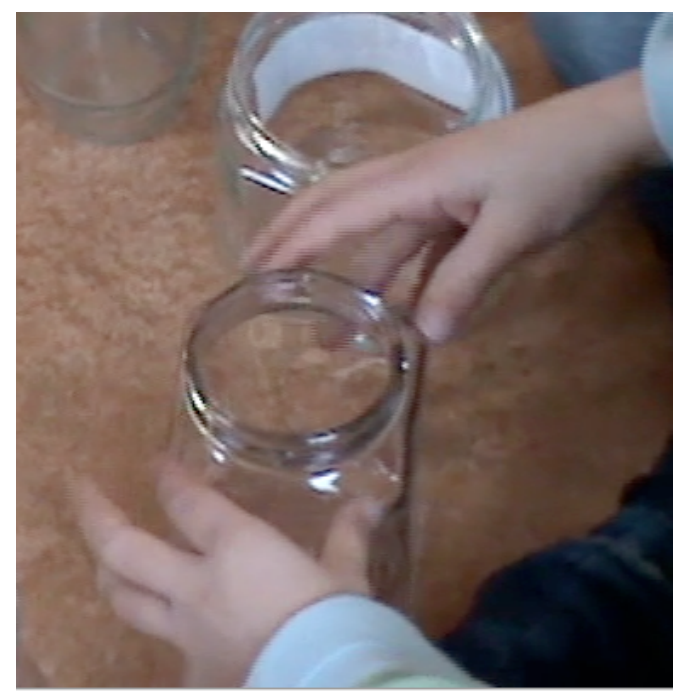

This helped the children to focus on different shapes both between the jars as well as within the jar. After a while the teachers asked if the children could put the jars in some sort of order. Lena placed all but one together in a group and explained how the odd jar was rectangular and therefore did not fit with the others.

After a short while, Mia tried to put her foot in one of the jars and Lena and Marie copied her immediately. 


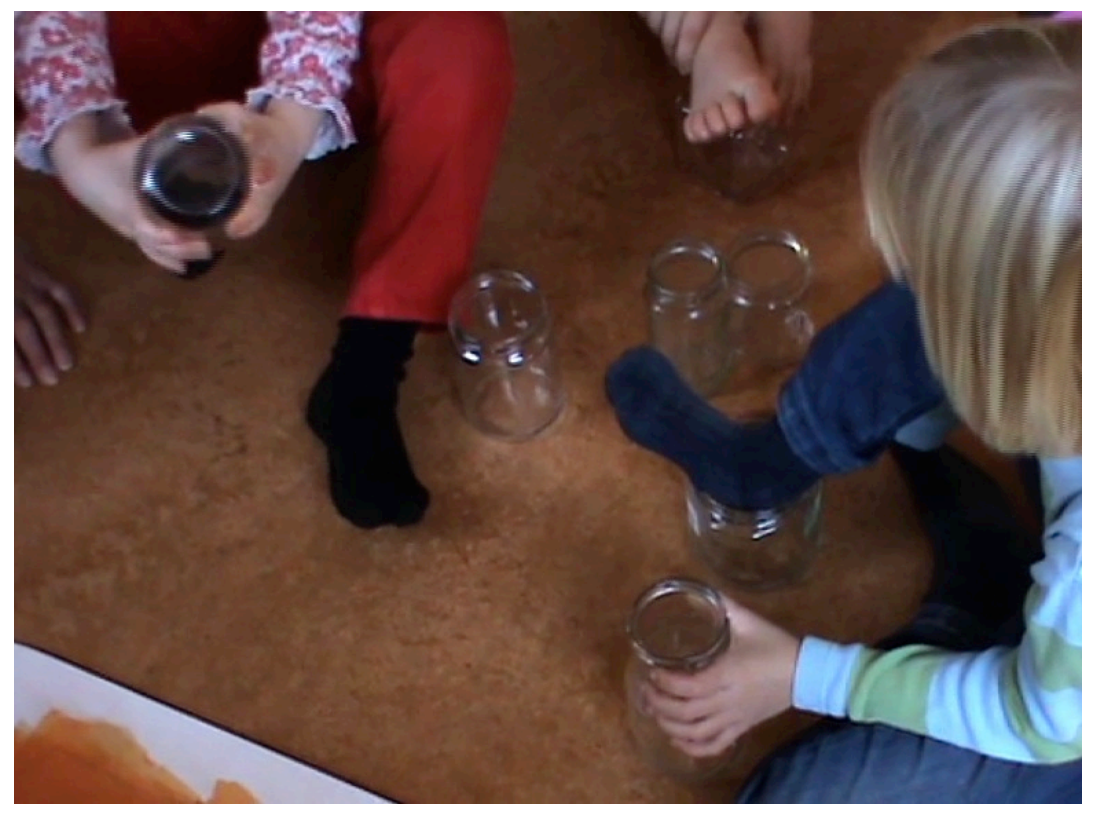

This went on until the teacher again asked the children if they could put the jars in order but this time she specified that the order was to be according to size. The children started to arrange the jars, with the teacher asking questions as they were doing it.

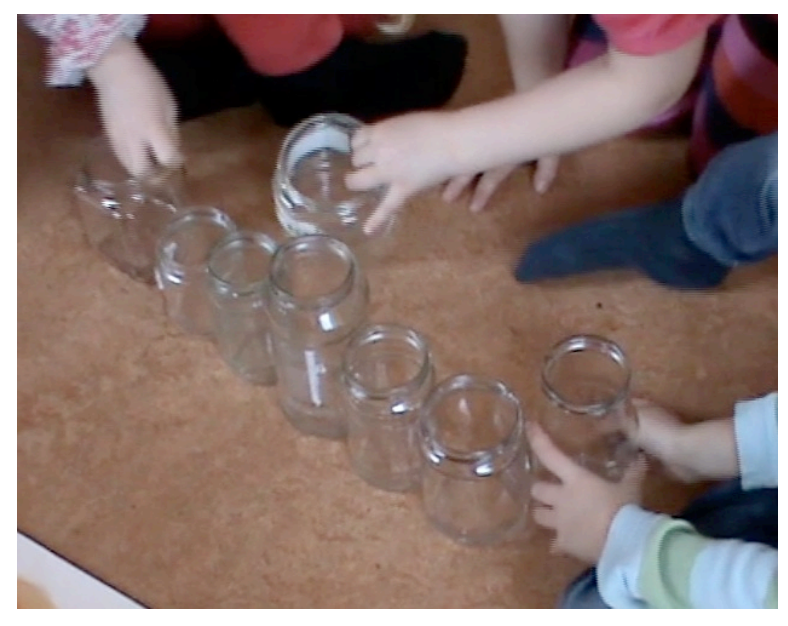

L: Vilken kan komma efter den här om den är högst och sen kommer den vilken kan komma efter den här? [Marie flyttar dit en högre burk] Om man tänker att man hitta What can come after if this is the tallest and then what could come after this? [Marie moves a taller jar into the line] Do you think that you could find one nått som är lägre än den?

Marie: Större.

\section{Bigger.}

L: $\quad$ Den är högre.

It is taller.

[Mia ändrar på burkarna så att de går från högre till lägre.]

[Mia changes the jars so they go from tallest to shortest.] 


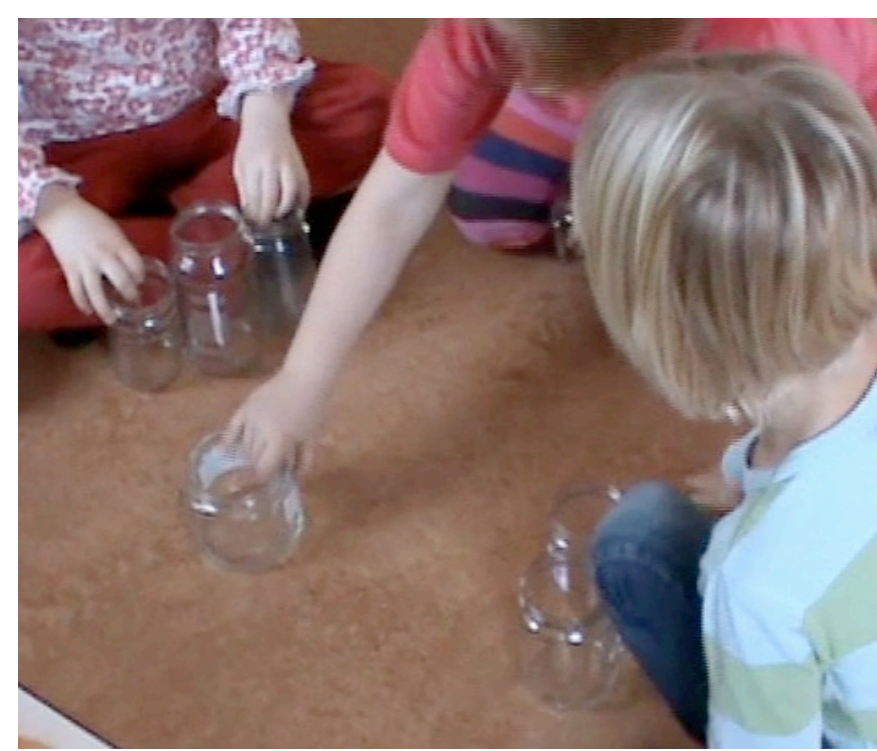

L: $\quad$ Om vi gör så att vi ställer tillbaka If we do so that we put them back to see dom också ser vi om vi alla kan få, if we can all get, put them back Marie all ställ tillbaka dom Marie allihopa, of them, if anyone can get three each? om alla kan få tre var?

Marie: En, två, tre [Marie räknar när hon tar sina, de andra bara tar]

L: $\quad$ Det gick inte att få tre var.

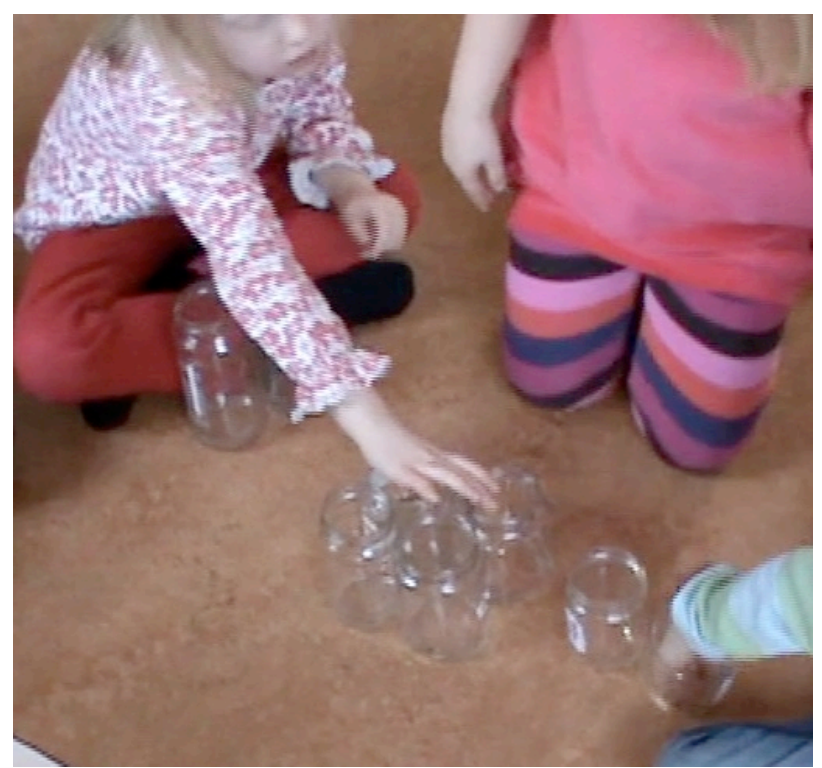

L: $\quad$ Åtta. Hur många fick du det till, Eight. How many did you get it, do you kommer du ihåg det? [till Marie] remember that? [Marie] when you när du räknade alla tillsammans? counted all together? [Marie shakes her [Marie skakar på huvudet]

Marie: Sju.
On the initiative of Marie they divided the jars between them. Marie said that everyone could have two each. The teacher then asked if they could have three each.

One, two, three [Marie counts as she takes hers, the others just take theirs]

Could not get three each.

Then they counted the jars. Marie counts seven whilst Lena counts eight. head] 
L: $\quad$ Marie fick det till sju

Marie: Nej, jag fick det till åtta.

L: $\quad$ Aha, du fick det till åtta sen, mm. Det är åtta tillsammans och vi har två var nu. Om vi gör så här att vi försöker ställa alla små burkar i en hög och alla stora burkar i en hög.
Marie got it [the answer] to be seven.

No, I got it to be eight.

Aha, you got it to be eight, then, mmm.

There are eight together and we have two each time. If we do like this that we try to put all the small jars in a pile and all the big jars in a pile.

By contrasting the answers the teacher made the girls aware that there were two different answers. However, Marie did not want to take this any further and then said that she got eight as well.

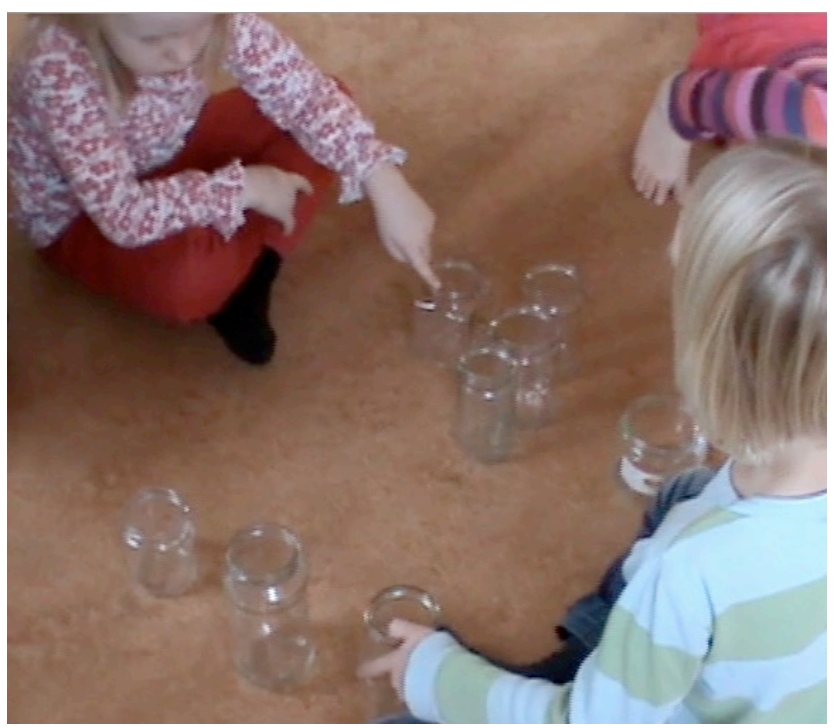

Then the teacher asked the girls to sort the jars with the small jars in one group and the tall ones in another group. Although it began as a discussion about size, all of a sudden Marie says fyrhörning (meaning a figure with four corners, i.e. a quadrilateral). This comment occurred when she was touching a jar with a square cross section. The teacher focused on this and they started to talk about the different shapes.

Throughout the episode, the teacher followed whatever the children were interested in. However, the repeated requests for the jars to be sorted according to some criteria, suggested that she did have a specific intention for the activity. Nevertheless, she followed the children's own interests and did not insist on them continuing to arrange the bottles according to different kinds of attributes. By being sensitive to the children's interest in the jars, she both caught and missed opportunities to challenge the children's understanding. For example, she was able to suggest seeing if it was possible for each person to have three jars each after Marie's suggestion of having two each had been investigated.

\section{ANALYSIS}

In the analysis, we look at each of Rogoff et al.'s (2003) components to see how representative the various incidents are of intent participation or assembly-line instruction. In making this analysis, we use Anghileri's (2006) strategies environmental provisions; explaining, reviewing and restructuring; developing conceptual thinking - to identify how the teacher developed the learning opportunities for the children. 


\section{Participation structures}

The teacher set out the jars so that the children could make candle holders. Possibly because the children began to handle the jars immediately, she invited them to play before the main task of making the candle holders. At different times, she requested the children to talk about the jars and to order them in different ways. However, in responding to the teacher's suggestions the children took control of how the activity developed through their actions or comments. Although the participation structures did not have the fluidity described by Rogoff et al. (2003) for intent participation, neither did they have the fixed roles of the assembly-line instruction.

This fluidity of control was supported by "provision of artefacts", a scaffolding strategy, from the environmental provision level, which was the lowest level of Anghileri's (2006) hierarchy. The provision of artefacts, the glass jars, scaffolded the children into playing which then lead to learning opportunities. The jars attracted and retained the children's interest and consequently they explored them in a variety of different ways, sometimes with teacher guidance but also by themselves. Providing the jars resulted in the children immediately touching and playing with them, which exemplifies level two of Anghileri's (2006) teacher strategies identified as "looking, touching and verbalising". The teacher could build on these tactile sensations by asking different children to verbalise what they noticed, thus bringing mathematical ideas such as shape and number into focus.

At times the children engaged with the jars individually, or in parallel, but at other times they worked together as was the case when they ordered the jars from shortest to tallest. According to Anghileri (2006), grouping as a way of working together is a form of scaffolding at the environmental provision level. Children's working together in this way, with the teacher sitting on the side, was a result of collaborative, horizontal participation structures. However, it may be that the value that the participants gave to this way of working then supported the use of those structures at other times. The control of the activity flowed between the different participants during these group work sessions.

\section{Roles}

In intent participation, "experienced people play a guiding role, facilitating learners' involvement and often participating alongside learners - indeed often learning themselves. New learners in turn take initiative in learning and contributing to shared endeavours, sometimes offering leadership in the process" (Rogoff et al., 2003, p. 187). In the activity, the teacher did not participate in the same way as the children and so her role was closer to that of a manager in assembly-line instruction. On the other hand, although she suggested activities, such as ordering the jars, she did not force the children to carry them out. Several times the children took the initiative in suggesting activities and so their role could be considered to be closer to that of intent participation. To structure their interactions, they used the ideas of each other, such as placing their feet in the jars, as much as they did the ideas of the teacher. Although 
they did not verbally interact with each other like they did with the teacher, they constantly watched and copied each other's actions.

Many of the teacher's questions focused the children on mathematical aspects of their jars. As part of her level 2 strategies, Anghileri (2006) identified the need for teachers "to interject questions that focus on the most critical points in an explanation and take the understanding forward. Here the purpose is to gain insight into students' thinking, promoting their autonomy and underpinning the mathematical understanding that is generated" (p. 42-43). Without the questions, these aspects may have been missed by the children. Therefore, the teacher's role as the one with expert knowledge was important. However, as noted earlier, the play situation meant that it was not always possible to push children's thinking because they were not required to answer the teacher's questions, as occurred when Mia was counting the jars.

Although the teacher may have known the answers to some of her questions, her way of listening to the children suggested that she was opening a learning space which accommodated their reflections. Thus, not only did the teacher ask prompting and probing questions but she left the children to interpret and answer the questions, which meant that children's autonomy was supported. Thus, her "listening" style was as important as her questioning style.

\section{Motivation and purpose}

After the children had begun to handle the jars, the teacher suggested that the beginning activities were play - "Men innan vi börjar med att göra dem här ljusen tänkte jag att vi kunde leka lite med de här burkarna. Tycker ni att alla burkar ser likadana ut?" ("But before we start making the candles here, I thought we could play around with these jars. Do you think that all the jars look alike?"). The video of the episode showed that the children continued to play with the jars, even though the teacher asked a school-like question. The characteristics of play identified by Dockett and Perry (2010), "the exercise of choice, non-literal approaches, multiple possible outcomes and acknowledgement of the competence of players" (p. 175) can be seen in how the children explored the jars. Consequently, the purpose of the activity was clear to all. By agreeing on the activity being one of play, the children were free to make choices about what they would do. It would not have been appropriate for the teacher to expect responses to her questions as in a school-like Initiation-ReplyEvaluation format (Rogoff et al., 2003) as this would have clearly changed the activity. The confining of participants' actions to those consistent with play can be seen as a significant contributor to the children engaging eagerly in the activities.

However, with the activity being labelled as play, many of the teacher scaffolding strategies identified by Anghileri (2006) were inappropriate unless they were adapted, such as was the case with teacher listening. One of Anghileri's level two strategies is "identifying meaningful contexts", which constitutes finding a shared context which makes the mathematical problem more accessible to students. This episode with preschool children suggests that working in a context that is meaningful for the 
children, that of play, and conforming to its characteristics, contributes to children engaging actively. When children have control over deciding if and how they want to engage then there is no need for a teacher to search for a meaningful context. Rather it is the level one strategies, connected to environmental provisions, which are more important as the teacher needs to provide materials with which the children will want to engage.

\section{Sources of Learning}

Rogoff et al. (2003) stated that "in intent participation, learning is based on participation in ongoing or anticipated activities, with keen observation and listening" (p. 22). The glass jar activity was not an adult activity where the children learnt from watching experts. Simply reading the transcript could suggest that the children merely responded to the teacher's questions as would be the case in assembly-line instruction. However, the video shows that as well as listening to the teacher, the children at the same time manipulated the glass jars and watched each other. Simultaneously noticing different behaviours is common in play, as the focus shifts frequently. Therefore, as in intent participation, the children paid attention to multiple ongoing events. In assembly-line instruction the focus is supposed to be concentrated on only one action. Children, who focus widely, are labelled as distracted and likely to have problems learning (Rogoff et al., 2003). Thus, because the activity was acknowledged as play, focusing widely provided a variety of sources for learning opportunities.

With the children focusing widely, there were opportunities for them to make connections between visual imagery and spoken words, a scaffolding strategy, developing representational tools, that Anghileri (2006) saw as being part of Level 3. Mia used the discussion between Marie and the teacher about "bigger" and "taller" as well as looking at and touching the jars to rearrange them from shortest to tallest.

\section{Forms of communication}

In the episode, the children's actions were often connected to language as a result of the teacher's questions. As discussed previously, the teacher's questions were sometimes about information that she already knew. As such, Rogoff et al. (2003) would consider that they were test questions and a form of communication linked to assembly-line instruction. Yet, the children responded to them as though they required genuine investigation. For example, the first request was about whether the children thought the jars were alike. Although the children and the teacher could see that there were differences, the children picked up the jars, felt them and then made comments about them. The teacher was not judgemental about the comments, but instead asked for clarification. The children made choices about whether to respond or not. This format for interaction would not be considered typical of intent participation where the expert provides explanations only within the context of the process being learnt. Nevertheless, the format for interaction made the mathematics visible in the exchange but kept the conversation within the children's control. For 
example, in suggesting that the children order the jars according to size, the children's actions in placing the jars in a row, provide the teacher with an opportunity to bring in comparison terms, an important component of measurement.

Most of Anghileri's (2006) scaffolding strategies can be considered forms of communication as they are concerned with how a teacher interacts with students. As already noted, many of the strategies were seen in this episode. At the highest level of scaffolding, Anghileri included "generating conceptual discourse" in which the teacher identifies for the students valuable ways of thinking mathematically, "thus enabling students to become aware of more sophisticated forms of mathematical reasoning" (p. 49). In the jar episode, the teacher's requests for clarifications rather than providing judgments about the children's answers may have supported them to see that their explanations were what the teacher valued, rather than a specific, correct answer. This is likely to contribute to them gaining "intellectual autonomy" (p. 49). However, there were opportunities for the teacher to request more information from the children about their mathematical thinking, such as was the case with the sharing of the jars so that each child had two each. It is interesting to note that she did not recognise or chose not to take up the possibility to have children think more about why sharing in twos was possible while sharing by threes was not and so missed an opportunity to push them into thinking more about the numbers and how they were related.

\section{Assessment}

In intent participation, assessment occurs continually during the performance of the activity with the intention of ensuring that children gain "the important skills and ways of their community" (Rogoff et al., 2003, p. 196). By being in a play situation, assessment requirements are not connected to the performance of a particular practice and do not determine the children's retention of set information, as is the case in assembly-line instruction. Yet, the preschool teacher was involved in continual assessment both of the children's willingness to engage, important in intent participation, but also of the mathematical information that they showed. Having children show the mathematics that they knew was not an end in itself but rather contributed to the play being continued and the mathematics becoming visible.

Anghileri (2006) suggested that negotiating meaning is one strategy that involves the teacher having to listen carefully:

It is time consuming and demanding on a teacher's skills to elicit the true meaning of their students' responses, respecting the more outlandish contributions as their students work at developing their personal understandings, and not simply opting for responses that are 'in tune' with their requirement. (Anghileri, 2006, p. 46)

Anghileri queries the need for teachers to insist that children always provide the "correct" meaning. Similarly, Krummheuer (2012) suggests that negotiating meaning occurs in every interaction: 
From an interactionist's stance, all interaction situations principally entail the potential of developing in a non-canonical way so that the participants cannot easily refer to routinized and/or standardized knowledge applications. In such cases, the participants have to interactively negotiate a novel "shared meaning". (p. 321)

When two children arrived at different total numbers of the jars, the teacher highlighted that there were differences but when Marie did not want to discuss the difference, but changed her answer to that of Lena, the teacher did not insist on Marie recounting. The teacher could assess the children's knowledge and note for future reference that it might be useful to provide activities where it was likely that Marie would need to count to eight again. Requiring Marie to count immediately after she had rejected an offer to discuss her answer may have decreased her willingness to participate in further activities and changed the activity from one of play to one of direct instruction which would be more closely aligned with assembly-line instruction.

\section{USING PLAY FOR TEACHING MATHEMATICS}

Too often, discussions about learning of mathematics in preschools are positioned as being a choice between direct instruction and free play. Although the importance of the teacher interactions in preschools have been noted in many studies, a clear description of what the teacher does to facilitate learning often remains unclear, especially within guided play situations. Our study indicates how conforming to the context of play affected both the children and the teacher's ways of interacting. Our analysis of each of Rogoff et al.'s (2003) components shows how the effect of the particular kinds of interactions which occurred then affected the possibilities for learning.

The play context supported the children's engagement, but also restricted how the teacher could interact with the children and the scaffolding that she provided. Level 1 scaffolding strategies were more important for setting up learning opportunities than Anghileri (2006) suggested, because the organisation of the environment is what supported the children to play. The play undertaken with the jars also resulted at level two in reviewing, rather than restructuring, strategies being used frequently by the teacher because they conformed more easily to the need for the children to have control of the activity. As the children controlled the activity, level 3 strategies had to build on what was offered by the children through their actions or words and so could not be easily initiated by the teacher independently.

At first glance, play and teaching mathematics do not seem to be compatible. Mathematics is often considered to be something that can only be learnt from direct instruction (Lange \& Meaney, 2011). Yet this example of a preschool interaction shows that guided play can provide rich opportunities for learning mathematics. It could be said that the teacher guided the children's actions, but was respectful of the children's control over the direction of the activity. The teacher was able to stimulate children's mathematical curiosity about shapes, their attributes and about number, 
including division. This curiosity, as well as the children's enjoyment, could be seen in the way that the children played with the jars and the mathematical ideas that they discussed. This episode does seem to illustrate the Swedish preschool curriculum's suggestion that play and enjoyment produces learning that would lead to "imagination, insight, communication and the ability to think symbolically, as well as the ability to co-operate and solve problems" (Skolverket, 2011, p. 6).

Nevertheless, by placing the teaching in a play situation the teacher's actions are constrained. Direct instruction also constrains the teacher's possibilities for interacting with the children, but in different ways. As was illustrated in this episode, play means that children have as much opportunity as the teacher, if not more, to control what happens. The focus of the activity can switch frequently supporting children to take note of a wide range of stimuli simultaneously. The teacher can offer suggestions for activities and ask questions about what the children are engaged in but the children can ignore the invitation or decline to participate. The teacher cannot insist that her suggestions are accepted as this would move the activity from one of being play into something more closely resembling Rogoff et al.'s (2003) assemblyline instruction. Consequently, the teacher must watch and listen very carefully to the children so that her suggestions build on the children's interests and also what they have previously shown about mathematical ideas. The questions and suggestions should raise the children's curiosity, if children are to engage with them willingly. If the teacher is successful in doing this, then the mathematical aspects of children's actions are made visible.

Thus, it is clear that the context has a substantial influence on children's possibilities for learning. This is not to suggest that play is a negative influence. Rather, like direct instruction, the possibilities for learning are constrained as well as enabled by the contexts in which these possibilities arise. In Sweden, the role of play as the context for learning is a long-standing belief, heavily supported within the curriculum (Skolverket, 2010; 2011).

However, this small study of one teacher's interactions suggest that for learning to develop over time, then the teacher's understanding about mathematics and how to develop children's mathematical curiosity within a play context is very important. Teachers need to both recognise mathematical learning opportunities and to formulate challenging questions, matching both children's interest and their current knowledge of mathematical ideas, if the joint aims of using play as the context for learning and to develop children's mathematical understanding are to be achieved. When the teacher is able to do this as happened in this episode, the children will make use of the control that they have from the activity being one of play and this is likely to contribute to learning being connected to enjoyment. 


\section{REFERENCES}

Anderson, A. (1997). Families and mathematics: a study of parent-child interactions. Journal for Research in Mathematics Education, 28(4), 484-511. Available from: http://www.jstor.org/stable/749684

Anghileri, J. (2006). Scaffolding practices that enhance mathematics learning. Journal of Mathematics Teacher Education, 9, 33-52. doi: 10.1007/s10857006-9005-9

Bishop, A. J. (1988). Mathematical enculturation: A cultural perspective on mathematics education. Dordrecht: Kluwer.

Björklund, C. (2008). Toddlers' opportunities to learn mathematics. International Journal of Early Childhood, 40(1), 81-95. doi: 10.1007/BF03168365

Carr, M., \& May, H. (1996). The politics and processes of the implementation of Te Whaariki, the New Zealand national early childhood curriculum 1993-6. In M. Carr \& H. May (Eds.), Implementing Te Whaariki (pp. 1-13). Wellington: Institute for Early Childhood Studies.

Coltman, P., Petyaeva, D., \& Anghileri, J. (2002). Scaffolding learning through meaningful tasks and adult interaction. Early Years: An International Journal of Research and Development, 22(1), 39-49. doi: 10.1080/09575140120111508

Dijk, E. F., van Oers, B., \& Terwel, J. (2004). Schematising in early childhood mathematics education: why, when and how? European Early Childhood Education Research Journal, 12(1), 71-83. doi: 10.1080/13502930485209321

Dockett, S., \& Perry, B. (2010). Playing with mathematics: Play in early childhood as a context for mathematicsl learning. In L. Sparrow, B. Kissane, \& C. Hurst (Eds.), Shaping the future of mathematics education: Proceedings of the 33th annual conference of the Mathematics Education Research Group of Australia, (pp. 715-718). Freemantle, Australia: MERGA Inc.

Doverborg, E. (2006). Svensk förskola [Swedish pre-school]. In E. Doverborg \& G. Emanuelsson (Eds.), Små barns matematik [Small children's mathematics] (pp. 1-10). Göteborg: NCM Göteborgs Universitet.

Edo, M., Planas, N., \& Badillo, E. (2009). Mathematical learning in a context of play. European Early Childhood Education Research Journal, 17(3), 325-341. doi: 10.1080/13502930903101537 
Emilson, A., \& Folkesson, A.-M. (2006). Children's participation and teacher control. Early Child Development and Care, 176(3-4), 219-238. doi: 10.1080/03004430500039846

Haynes, M. (2000). Mathematics education for early childhood: A partnership of two curriculums. Mathematics Teacher Education \& Development, 2, 93-104. Available from: http://www.merga.net.au/node/43?volume $=2$

Krummheuer, G. (2012). The "non-canonical" solution and the "improvisation" as conditions for early years mathematics learning processes: The concept of the "interactional niche in the development of mathematical thinking" (NMT). Journal für Mathematik-Didaktik, 33(2), 317-338.

Lamberty, K. K. (2007). Getting and keeping children engaged with a constructionist design tool for craft and math. Unpublished $\mathrm{PhD}$ thesis. Atlanta, GA: Georgia Institute of Technology. Available from http://smartech.gatech.edu/jspui/bitstream/1853/14589/1/lamberty_kristin_k_2 00705 phd.pdf

Lange, T., \& Meaney, T. (2011). Preservice teachers learning mathematics from the internet. In J. Clark, B. Kissane, J. Mousley, T. Spencer, \& S. Thornton (Eds.), Mathematics: Traditions and (new) practices: Proceedings of the 34th annual conference of the Mathematics Education Research Group of Australia and the Association of Mathematics Teachers, (pp. 438-445). Adelaide: AAMT and MERGA. Available from http://www.merga.net.au/node/38?year=2011

Lee, J. S., \& Ginsburg, H. P. (2009). Early childhood teachers' misconceptions about mathematics education for young children in the United States. Australasian Journal of Early Childhood, 34(4), 37-45. Available from:

http://www.earlychildhoodaustralia.org.au/australian_journal_of_early_childho od/ajec index_abstracts/ajec_vol 34_no_4_december_2009.html

Papic, M. M., Mulligan, J. T., \& Mitchelmore, M. C. (2011). Assessing the development of preschoolers' mathematical patterning. Journal for Research in Mathematics Education, 42(3), 237-268.

Rogoff, B., Paradise, R., Arauz, R. M., Correa-Chávez, M., \& Angelillo, C. (2003). Firsthand learning through intent participation. Annual Review of Psychology, 54, 175-203. doi: 10.1146/annurev.psych.54.101601.145118

Samuelsson, I. P., \& Carlsson, M. A. (2008). The playing learning child: Towards a pedagogy of early childhood. Scandinavian Journal of Educational Research, 52(6), 623-641. doi: 10.1080/00313830802497265 
Sheridan, S., Samuelsson, I. P., \& Johansson, E. (2009). Barns tidiga lärande: Et tvärsnitsstudie om förskolan som miljö för barns lärande [Children's early learning: A cross-sectional study of preschool as an environment for children's learning]. Göteborg studies in educational sciences 284. Göteborg: Acta Universitatis Gothoburgensis. Available from https://gupea.ub.gu.se/handle/2077/20404

Skolverket (2010). Läroplan för förskolan Lpfö 98: Reviderad 2010. Stockholm: Skolverket.

Skolverket (2011). Curriculum for the Preschool Lpfö 98: Revised 2010. Stockholm: Skolverket.

Wood, D., Bruner, J. S., \& Ross, G. (1976). The role of tutoring in problem solving. Journal of child psychology and psychiatry, 17(2), 89-100. 